\title{
A ZENEI NEVELÉS HELYZETÉNEK VIZSGÁLATA A FÜZESABONYI KISTÉRSÉG ÓVODÁIBAN
}

\author{
Szerző: \\ Szabadkai Vanda
Eszterházy Károly Katolikus Egyetem \\ Szabadkai Vanda
Eszterházy Károly Katolikus Egyetem
}

Szerző e-mail címe:

szabadkaivanda008@gmail.com

\author{
Lektorok: \\ Mező Ferenc (PhD) \\ Eszterházy Károly Katolikus Egyetem \\ Klem Dénes \\ Eszterházy Károly Katolikus Egyetem \\ ...és további két anonim lektor
}

\begin{abstract}
Absztrakt
A tanulmány az óvodai, illetve a családokban folyó zenei nevelés gyakorlati megvalósulásának vizsgálatával foglalkozik. Kutatásunkat a füzesabonyi kistérség négy óvodájában végeztük. Vizsgálatunk során a kérdőív, az interjú, a megfigyelés és a dokumentumelemzés módszerét alkalmaztuk. Az eredményekből kiderült, hogy a szülők sok esetben nincsenek tisztában az otthoni zenei nevelés helyes módszereivel, illetve a megfelelő, élményt nyújtó zenei nevelés esetenként az óvodákban sem valósul meg teljes mértékben. Kiderült továbbá, hogy a vizsgált óvodákban a szülők és az óvodapedagógusok közt a kapcsolattartás hiányosságokat mutat a zenei nevelés területén.
\end{abstract}

Kulcsszavak: zenei nevelés, óvoda, családi hatások, kapcsolattartás

Diszciplína: neveléstudomány

\begin{abstract}
INVESTIGATING MUSIC EDUCATION IN THE PRE-SCHOOLS OF THE FÜZESABONY REGION

The study investigates the practical implementation of music education in kindergartens and families. Our research was carried out in four kindergartens of the Füzesabony small region. In the course of our research, we used the method of questionnaire, interview, observation, and document analysis. The results show that in many cases, parents are not aware of the correct methods of the home music education, and that appropriate, experiential music education is sometimes not fully implemented
\end{abstract}


in kindergartens. It was also found that in the examined kindergartens, the communication between parents and kindergarten teachers shows shortcomings in the field of music education.

Keywords: music education, kindergarten, family influences, contact

Disciplines: pedagogy

Szabadkai Vanda (2021): A zenei nevelés helyzetének vizsgálata a füzesabonyi kistérség óvodáiban. OxIPO - interdiszciplináris tudományos folyóirat, 2021/3, 49-79.

doi: 10.35405/OXIPO.2021.3.49

Napjainkban a számos, a koragyermekkori zenei nevelés sokoldalúan fejlesztő hatását igazoló bel- és külföldi kutatás (Kokas, 1972, Barkóczy és Pléh, 1977, Rauscher, 2003, Net1, Janurik, 2008) eredménye ellenére az értékválasztásukban igényes, zeneszerető emberek nevelése egyre inkább elmarad. Bár a szülők próbálják tudatosan nevelni gyermekeiket, a közös zenei élményszerzés a családok többségében háttérbe szorul, vagy helytelen módon valósul meg, így a megfelelő zenei nevelés feladata főként az óvodákra, iskolákra hárul. Mivel a zenei ízlés és a zenei képességek fejlődése szempontjából az egyik legszenzitívebb időszak a 3-7 éves kor, fontos lenne, hogy a gyermekek az óvodában már megfelelő zenei nevelésben részesüljenek (Szarkáné Horvát, 1995).

Az elmúlt években több hazai kutatás is foglalkozott a koragyermekkori zenei nevelés transzfer hatásaival és a zenei képességek fejlesztésével, fejlődésével (Gévayné Janurik, 2010, Janurik és Józsa, 2013), jelentősége ellenére azonban kevés figyelem irányult az óvodáskori zenei nevelés gyakorlati megvalósulásának vizsgálatára. Jelen tanulmányunk célja az óvodai, illetve a családokban folyó zenei nevelés gyakorlati megvalósulásával kapcsolatos empirikus adatok bővítése. A munka elméleti része az otthoni zenei háttér szerepét, az óvodáskori zenei nevelés legfőbb elveit és törvényi kereteit mutatja be, a tanulmány második felében pedig ismertetésre kerülnek kutatásunk eredményei.

\section{A családi háttér szerepe a gyermek zenei fejlődésében}

A családi háttér meghatározó szerepét Kodály Zoltán már az 1900-as évek közepén felismerte, szocializációja során ugyanis ebben a környezetben találkozik először zenével a gyermek, és nagyon sokáig csak azt fogyasztja, amit a szülői ház közvetít felé. Gyermeknapi beszédében ezért is igyekezett felhívni a figyelmet a szülők felelősségére, nekik kell 
ugyanis az érzelmi nevelés fontosságát belátva minél hamarabb megkezdeni gyermekük zenei nevelését (Kodály, 1982).

Napjainkra már számtalan hazai és külföldi kutatás támasztotta alá eredményeivel Kodály elképzelését, miszerint a család hátterének, annak társadalmi, kulturális és anyagi helyzetének, illetve az otthoni zenei környezetnek kiemelkedő szerepe van a gyermek zenei képességeinek korai fejlődésében (Turmezeyné Heller és Balogh, 2009). A kutatók különböző életkorú gyermekek zenei képességeit vizsgálva kimutatták, hogy a zenei képességeket több aspektusból mérő „Seashore-tesztben való eredményességben is megmutatkozik az otthoni zenei környezet hatása mind az általános, mind a középiskolás, mind a föiskolás korosztály esetében” (Gévayné Janurik, 2010, 52.o.). Összefüggéseket találtak továbbá a családok zenehallgatási szokásai és a felnövő gyermek későbbi zenei ízlése között is, vizsgálatokból ugyanis kiderült, „hogy elsősorban azok a diákok hallgatnak komolyzenét, akiknek otthon a szülei is hallgatnak." (Harmat, 2005, 96.o.) Több kutatás is kimutatta, hogy hangok észlelésére már a magzat is képes, „a még meg nem született gyermek nemcsak reagál a zenére, hanem rendelkezik zenei kompetenciákkal, zenei preferenciákkal, amelyek összefüggést mutatnak a várandós anya zenei környezetével. Jóllehet az újszülött több zenei képességgel is rendelkezik, azonban megfelelő megerősítés nélkül az első hónapok után ezek el is tûnnek"
(Turmezeyné Heller és Balogh, 2009, 64.o.). Ajánlott tehát a leendő édesanyák számára, hogy már magzati és újszülött korban énekeljenek gyermeküknek és hallgassanak nyugodt, lassú komolyzenei tételeket.

A tömegmédia hatására a zene ma már mindenki számára minden pillanatban elérhető, ez pedig nagyban megváltoztatta a családok zenehallgatási, együtt éneklési, zenélési szokásait. A gyermek zenei érdeklődésének elindítása szempontjából elengedhetetlen aktív zenélésen, a szülő és a gyermek közötti személyes kapcsolaton alapuló közös éneklést és mondókázást napjainkban egyre inkább felváltja a gépzene. Habár a különféle zenei neveléssel foglalkozó szakirodalmak számtalan helyen felhívják a figyelmet a túlzott médiafogyasztás gyermekekre gyakorolt káros hatásaira, egyes kutatások eredményei szerint nem ritka, hogy az otthonokban a különféle IKT eszközökből szóló, sokszor csak háttérzajként alkalmazott könynyűzene hallgatásával a gyermekek naponta akár 2-3 órát is eltöltenek, sok esetben teljes szülői kontroll nélkül. Ezzel a gyakorlattal szemben viszont fontos lenne, hogy a szülő gondosan megválogassa a gyermekének szánt zenei műsorokat, figyelmét pedig a neki való, értékes zenei anyagok felé irányítsa, még akkor is, ha ez a szelektálás egyre nehezebb feladat a manapság gyorsan bővülő, esetenként nem az értékes zenét képviselő gyermekeknek szóló zenei kiadványok között (Vargha és tsia, 1976). 
Lényeges lenne a továbbiakban az is, hogy a szülő lehetőségeihez mérten minél többször biztosítson a közös játékra, zenehallgatásra, éneklésre olyan alkalmat, amikor mindketten csak a közösen végzett tevékenységre koncentrálnak, és énekeljen gyermekének minél többször különféle neki való gyermekdalokat. Pozitívan befolyásolja a gyermek zenei fejlődését továbbá, ha környezetében megtalálhatók a különféle boltban vásárolt hangszerek, illetve a szülővel közösen készített játékhangszerek (Vargha és tsai, 1976).

\section{Az óvodai zenei nevelés alapelvei}

Óvodai zenei nevelésünk máig érvényes alapelveit híres zeneszerzőnk és zenetudósunk, Kodály Zoltán dolgozta ki az 1940-es évek elejétől kezdve. Az alapokat az 1941-ben megjelent Zene az óvodában c. tanulmányában tette le, melyben a 3-7 éves kor között szerzett tapasztalatok és benyomások egész életre szóló hatását felismerve elsőként tisztázta az óvodai zenei nevelés pótolhatatlan szerepét (Kodály, 1982). Ennek megfelelően szorgalmazta az óvodákban a mindennapos közös éneklés bevezetését, de előadásai során sokszor hangsúlyozta, hogy ez csak jól megválogatott, a 3-7 éves korosztály életkori sajátosságainak megfelelő, félhangot nem tartalmazó, 5-6 hangterjedelmú magyar gyermekdalok, mondókák, népdalok, az ezek szellemében komponált műdalok, valamint az egyéb igényesen megválogatott komponált zenei darabok segítségével valósulhat meg. Kijelentette, hogy a gépzene helyett az élményszerű zenetanítás, a tapasztaláson alapuló ismeretszerzés, az aktív zenélés, a személyes éneklés és zenehallgatás vezet zeneértéshez. Már óvodás korban fontos szerepet szánt a zenei képességek fokozatos, a gyermekek fejlődéséhez, egyéni és életkori sajátosságaihoz igazodó fejlesztésének, valamint a gyermekek zenei képességeit ebben az életkorban a legjobban kibontakoztató, mozgással összekötött népi énekes játékok óvodában történő rendszeres és változatos alkalmazásának (Kodály, 1982).

A Kodály által megalkotott zenei nevelési elveket az 1970-es években Forrai Katalin formálta egységes pedagógiai rendszerré. Az 1974-ben írt, közel negyed évszázados zenetudományos és óvodapedagógusi tapasztalatait összegző Ének az óvodában c. könyve a mainapig az óvodai nevelőmunka alapját képezi; a benne foglalt módszertani elvek segítséget nyújtanak az eltérő egyéni adottságokkal és fejlődési sajátosságokkal rendelkező óvodás gyermekek zenei képesség-fejlesztésének tervezéséhez, valamint személyiségfejlesztéséhez. Rendszerében - Kodályhoz hasonlóan - kiemelt szerepet kap a gyermekek számára maradandó élményt nyújtó, zenei érdeklődésüket felkeltő, éneklési kedvüket fokozó, egyéni és életkori sajátosságaikat figyelembe vevő, előzetes tapasztalataikra építő, az egyszerū zenei formáktól az egyre összetettebb elemek felé haladó, 
mindennapos, közös éneklésre alapozott, komplex személyiségfejlesztést megvalósító óvodai zenei nevelés, amely figyelembe veszi a zenei közművelődés távlati céljait is. Hangsúlyozza a közvetlen élő zene, a tapasztaláson alapuló, játékos zenei ismeretszerzés jelentőségét, illetve az éneklés, a zene, a mozgás és a játék összekapcsolásának elemiségét. (Forrai, 2016)

Szorgalmazza a zenei képességfejlesztés - óvodában elsôsorban az éneklési, ritmikai, hallási, zenehallgatási készség, a zenei alkotókedv, valamint a formaérzék fejlesztésének - koragyermekkorban történő elkezdését, de figyelmeztet ennek mindenkori játékos formában történő megvalósítására. Az óvodai ének-zenei tevékenység alapjának a népi énekes játékokat tekinti, de emellett kiemeli a mondókák szerepét is. Kodály elveit alapul véve kritériumokat fogalmaz meg az óvodai énektanítás dal, mondóka, valamint zenehallgatási anyagát illetően: véleménye szerint az óvodai zenei nevelés kezdetén a saját néphagyományból kiinduló, magyar népi énekesmondókás gyermekjátékok és a művészi értékű, magyar népzenei sajátosságokra épülő komponált gyermekdalok a legalkalmasabbak, majd ezek később fokozatosan kiegészülnek igényes műzenei alkotásokkal, illetve más népek dalaival is. Fontos, hogy a gyermekeknek szánt dalanyag szövege, hangterjedelme - pentatónia hangjai (kiscsoportban 3-4 (esetleg 5) hangterjedelem, középső- és nagycsoportban 3-6 hangterjedelem) -, ritmusa (egyszerū, föként negyed és nyolcad-pár váltakozása), lüktetése (páros lüktetés), tempója az adott gyermekcsoport életkori sajátosságához igazodjon. (Forrai, 2016)

Írásaiban sokszor felhívja a figyelmet az ének-zenei tevékenységek tudatos tervezésének jelentőségére, valamint ehhez kapcsolódóan az óvodapedagógusok módszertani szabadságára; az Óvodai Nevelés Országos Alapprogramja ugyanis megadja nekik azt a lehetőséget, hogy zenei előképzettségükre alapozva megvalósíthassák saját ötleteiket, elképzeléseiket és személyes meglátásuk szerint kiválasszák azt a módszert, ami véleményük szerint az adott csoport összetételéhez és életkori sajátosságaihoz leginkább illik (Forrai, 2016).

Újdonság nála, hogy kitér a család és az óvoda kapcsolatára is, felismeri, hogy ,az óvoda csak a családdal együtt tudja vállalni a felelősséget a gyermek egészséges fejlődéséért." (Forrai, 2016, 131.o.) Kihangsúlyozza, milyen fontos lenne, hogy az óvodapedagógus tájékoztassa a szülőket a gyermekük zenei fejlődéséről, megismertesse velük az óvodában tanult dalokat, mondókákat, esetleg jó tanácsokkal lássa el őket, ha bizonytalanok gyermekük zenei nevelését illető kérdésekben (Forrai, 2016).

\section{Az óvodai zenei nevelést meghatározó jogi keretek}

Magyarországon jelenleg az óvodákban folyó pedagógiai munka alapelveit a 363/2012. (XII. 17.) Kormányrendelet az 
Óvodai nevelés országos alapprogramjáról (A továbbiakban: Alapprogram) határozza meg.

Az Alapprogram fő célkitűzésének tartja, hogy a gyermekek megfelelő személyi és tárgyi környezet mellett egyenlő eséllyel részesüljenek a gyermeki személyiség teljes kibontakoztatására törekvő, egyéni és életkori sajátosságaikhoz igazodó, differenciált, egyéni készségeiket és képességeiket fejlesztő, gyermekközpontú óvodai nevelésben, mely a családi nevelés kiegészítőjeként a gyermekek eltérő képességeit, fejlődési ütemét figyelembe véve elősegíti az egyes területeken esetlegesen fellépő hátrányok csökkentését. Az óvó-védő, szociális és nevelő-személyiségfejlesztő funkciók ellátása mellett az óvodai nevelés célja, hogy a gyermekek különféle, heti rendszerességgel megszervezett, egyéni és életkori sajátosságaiknak megfelelő műveltségtartalmakat közvetítő, játékos, fokozatosan növekvő időtartamú csoportos foglalkozások mellett az iskolába lépés idejére megfelelő testi, értelmi és szociális érettséget érjenek el. A gyermekek egészséges, tevékenységekben megnyilvánuló fejlődéséhez és fejlesztéséhez az Alapprogram hét fó tevékenységterületet határoz meg, melyek mindegyike, így az „Ének, zene, énekes játék, gyermektánc” tevékenység is a gyermekek személyiségének és az iskolai élet megkezdéséhez szükséges általános és speciális képességeinek és készségeinek fejlődését segíti elő, elengedhetetlen szerepet betöltve ezzel az óvoda tervszerū nevelési folyamatában (Net2).

A pedagógiai munka hatékony megszervezéséhez az Alapprogram a tevékenységi formák alpontjain belül különféle megállapításokat, irányelveket fogalmaz meg az óvodapedagógusok számára az óvodai neveléssel kapcsolatban. Az „Ének, zene, énekes játék, gyermektánc” c. alponton belül kiemeli, hogy „Az óvodában a környezet hangjainak megfigyelése, az ölbeli játékok, a népi gyermekdalok, az éneklés, az énekes játékok, a zenélés örömet nyújtanak a gyermeknek, egyben felkeltik zenei érdeklődését, formálják zenei ízlését, esztétikai fogékonyságát. Az élményt nyújtó közös ének-zenei tevékenységek során a gyermek felfedezi a dallam, a ritmus, a mozgás szépségét, a közös éneklés örömét" (Net2). Felhívja a figyelmet a népdalok, gyermek- és néptáncok és énekes népi játékok fontos hagyományőrző szerepére, de emellett az igényesen megválasztott kortárs művészeti alkotások jelentőségét is hangsúlyozza, ugyanis ezek egyaránt a gyermek zenei képességeinek fejlesztését szolgálják, illetve nagyban hozzájárulnak a gyermekek zenei kreativitásának alakításához is. Szorgalmazza, hogy a zenehallgatási anyag megválasztása során - a népdalok és a komponált gyermekdalok mellett - az óvodapedagógus a gyermekek nemzetiségi hovatartozását is vegye figyelembe, amennyiben az óvoda nemzetiségi nevelést végez. Az Alapprogram célként tűzi ki, hogy az éneklés és a zenélés a gyermekek mindennapi tevé- 
kenységének részévé váljon, elősegítve ezzel zenei anyanyelvük kialakulását. Meghagyja viszont az óvodapedagógusoknak azt a szabadságot, hogy saját meglátásuk szerint döntsenek arról, milyen formában (kötött, kötetlen, komplex tevékenység az egész csoportrészvételével vagy mikrocsoportos formában, spontán vagy tervezett tevékenység formájában), milyen módszerrel, dal- és mondókaanyaggal, a hét melyik napján, illetve a napirend mely időszakában kerítenek sort a gyermekek előzetes tapasztalataira építő, életkori sajátosságaikat és egyéni készségeiket, képességeiket figyelembe vevő, az adott intézmény pedagógiai programjában leírtaknak megfelelő differenciált énekzenei tevékenységekre (Net2).

\section{Problémafelvetés és hipotézisek}

Kutatásunk célja az óvodai, illetve a családokban folyó zenei nevelés gyakorlati megvalósulásának vizsgálata volt. Kutatásunk során öt hipotézist fogalmaztunk meg:

1. Az általunk vizsgált óvodákban a zenei nevelés és képességfejlesztés az óvodák pedagógiai programjában leírtaknak, és az Óvodai nevelés országos alapprogramjának megfelelően, a gyermekek életkori sajátosságait, egyéni képességeit figyelembe véve, differenciált módon valósul meg.

2. Amennyiben az óvodákban megvalósul a megfelelő, élményt nyújtó zenei nevelés, úgy a gyermekek otthon is szívesen és gyakran éneklik a tanult dalokat.

3. Jelentős különbségek tapasztalhatók a magasabb és alacsonyabb iskolai végzettségű szülők gyermekei, a jó és rossz szociokulturális háttérrel rendelkező gyermekek, illetve a magyar és roma etnikumú gyermekek zene iránti érdeklődésében, valamint zenei képességeik, készségeik fejlődésének idejében és tempójában.

4. A szülők többsége érzi a zenei nevelés fontosságát, a magasabb iskolai végzettséggel rendelkező szülők pedig tudatosan jobb zenei hátteret biztosítanak gyermekeiknek, sok esetben azonban alacsonyabb iskolai végzettséggel rendelkező társaikhoz hasonlóan - még ők sincsenek tisztában az otthoni zenei nevelés helyes módszereivel.

5. A vizsgált régió óvodáiban a szülők és az óvodapedagógusok közötti kapcsolat hiányosságokat mutat a zenei nevelés terén.

\section{Minta}

Vizsgálatunkat a füzesabonyi kistérség négy óvodájában végeztük. Az óvodák négy, Egertől 25-35 km-re fekvő településen helyezkednek el. Etnikai hovatartozás, képzettség, gyermekek száma, anyagi viszonyok és lakáshelyzet szempontjából a lakosság mind a négy településen nagyon vegyes összetételű, nagymértékű a munkanélküliség, sokan segélyekből, alkalmi munkából élnek. A családok mentális és szociális körülményei igen eltérőek. Növekszik a hátrányos és halmozottan 
hátrányos helyzetű családok száma, a gyermekek egy része ingerszegény környezetből érkezik óvodába. Egyre többen küzdenek közülük magatartási, tanulási, és beilleszkedési zavarral, valamint beszédhibával, sokuk pedig alacsony szokás és szabálytudattal rendelkezik. Ismereteik, szokásrendszerük, neveltetési szintjük az óvodába kerülés pillanatakor nagyon eltérő, az ebből adódó fejlődési eltérések nagy kihívás elé állítják az óvodapedagógus hiánnyal küzdő óvodákat. A települések mindegyikén egy-egy óvoda működik, átlagot nézve az óvodákba járó gyermekek kb. 60\%-a a roma etnikumhoz tartozik.

Kutatásunk során a családokban folyó zenei nevelés vizsgálatához kérdőíves módszert használtunk. Szülői kérdőívünk kiosztására a vizsgált óvodákba járó gyermekek szülei közt került sor. Mivel a szülőket személyesen nem ismertük, ezért a kérdéssor kiosztásához az ott dolgozó óvodapedagógusok segítségét kértük, így kérdőívünk az éppen hiányzó gyermekek szüleihez is eljutott, és elkerülhető volt, hogy testvérpárok esetén egy családhoz több kérdőív is kerüljön. Ezt a kérésünket egy óvoda az óvodapedagógusok túlterheltségére hivatkozva elutasította, de biztosított számunkra egy napot, amikor a kérdőíveket személyesen kioszthattuk a gyermekükkel óvodába érkező szülők közt. A végleges mintanagyságot így ezen a helyszínen a kérdőív kitöltését visszautasítók mellett az aznap hiányzó gyermekek száma is befolyásolta. Az óvodák- ban összesen 321 db kérdőív kiosztására került sor, a kérdéssorra összesen 143 főtől érkezett válasz. A kérdőívek közül 5 $\mathrm{db}$ értékelhetetlennek bizonyult, így releváns mintának a maradék 138 kérdőívet tekintjük.

$\mathrm{Az}$ óvodai zenei nevelés megvalósulásának vizsgálatához a dokumentumelemzés, a megfigyelés és az interjú módszerét alkalmaztuk. A dokumentumelemzéshez a vizsgált óvodák pedagógiai programjainak zenei részeit használtuk fel. Megfigyelésre minden óvoda egy-egy csoportjában egyszeri alkalommal került sor egy-egy „Ének, zene, énekes játék, gyermektánc" tevékenység alkalmával: „A” óvodában egy 19 főből álló nagy; „B” óvodában egy 26 fős vegyes; „C” óvodában egy 25 fós vegyes; és „D” óvodában egy 21 főből álló szintén vegyes csoportban. Az interjúkat a későbbiekben ugyanezen csoportoknak a megfigyelések során az énekes tevékenységet tartó óvodapedagógusaival vettük fel, akik közül egy fél éve, egy 20 éve, egy 30 éve, egy pedig 45 éve dolgozik óvodapedagógusként a pályán.

\section{Eszközök}

A szülői kérdőív 19 kérdésből állt (lásd: 1. sz. melléklet). A kérdések közt 1 nyilt, 18 zárt, ezeken belül 7 alternatív, 6 feleletválasztós, 4 félig zárt kérdés és 1 deszkriptív skála szerepelt. Ezek egy része a zenének, a zenei nevelésnek a családok életében betöltött szerepét, a családok zenehallgatási, éneklési, együtt zenélési 
szokását, a szülők tájékozottságát, a gyermekek zenei érdeklődését, hátterét igyekezett felmérni; míg más részük az óvodai zenei nevelés gyermekekre gyakorolt hatását, illetve a szülők és az óvoda e téren történő kapcsolattartását, együttmúködését vizsgálta. Demográfiai jellegű kérdések közül kérdőívünk elején csupán egy, a kitöltők iskolai végzettségére vonatkozó kérdést tettünk fel. Válaszlehetőségként a 8 általánosnál alacsonyabb, a 8 általános, a szakiskola, a szakmunkásképző, az érettségi, a felsőfokú szakképzettség, a főiskolai diploma, az egyetemi diploma, és a doktori cím lehetőségeket adtuk meg; elemzésünk során pedig a határt a magasabb és az alacsonyabb iskolai végzettség között a szakmunkásképző fölött húztuk meg.

Az „Ének, zene, énekes játék, gyermektánc" tevékenységek megfigyelése során kötött, előre meghatározott szempontsort használtunk. Rögzítési technikaként hospitálási naplót és teljes jegyzőkönyvezést alkalmaztunk, melyben igyekeztünk minden, a későbbiekben szükséges verbális és nonverbális megnyilvánulást, illetve téri és időbeli viszonyt lejegyezni. A megfigyeléshez és a megszerzett anyag elemzéséhez Szarkáné Horváth Valéria: Az óvodai ének-zene foglalkozások módszertana c., 1995-ben kiadott könyvében található, „Az óvodai énekzene foglalkozások elemzésének szempontjai" alcím alatt szereplő szempontsort vettük alapul.
A harmadik eszközünk egy 22 kérdéskörből álló félig strukturált interjú volt, melynek kérdései öt témakör köré csoportosultak (lásd: 2. sz. melléklet). Egy részük az óvodába érkező gyermekek etnikai és szociokulturális hátterére; az óvodások zenei hátterére, zenei ízlésére, zenei készségeik, képességeik fejlődésére; más részük pedig az óvodában folyó zenei nevelésre, képességfejlesztésre; az óvodapedagógusok zenei felkészültségére, az általuk alkalmazott módszerekre; valamint a szülők és az óvoda közötti, a zenei nevelés terén történő kapcsolattartásra vonatkozott.

\section{Eljárás}

Szülői kérdőívünket 2019 októberében papír alapon osztottuk szét. Ez a forma a későbbiekben az adatok összesítésénél, elemzésénél kissé megnehezítette a feladatunkat, azonban úgy gondoljuk, az online formájú kérdőív nem múködött volna ilyen hatásosan, mert azt a formát olyan szülő is kitölthette volna, akinek gyermeke nem a vizsgált térség óvodáiba jár, illetve nem biztos, hogy az internetes kérdőív eljutott volna minden, a kutatásban érintett szülőhöz; így az általunk kapott eredmények nem lettek volna relevánsak. A kérdőívek értékelése során a Microsoft Excel és SPSS programokat használtuk. Statisztikai teszteket azzal a céllal futtattunk le, hogy rávilágítsunk arra, hogy az egyes almintáink mely kérdésekben fogalmaztak meg szignifikánsan különböző véleményt. A teszt eredményei alapján 
nem kívánunk általános, az egész alapsokaságra vonatkozó állításokat megfogalmazni, megállapításaink csupán a saját mintánkra érvényesek.

A kvalitatív módszerek közül elsőként a dokumentumelemzés módszerét alkalmaztuk. A programok zenei fejezeteinek tartalmi elemzésével fó célunk az volt, hogy megnézzük, az Óvodai nevelés országos alapprogramjának zenei nevelési irányelvei, valamint Kodály Zoltán és Forrai Katalin zenei nevelési módszerei hogyan jelennek meg az óvodák pedagógiai programjaiban.

Az „Ének, zene, énekes játék, gyermektánc” tevékenységek megfigyelését 2020 januárjában nyíltan, az óvodavezetőkkel és a megfigyelt személyekkel előre egyeztetett alkalommal végeztük. A megfigyelések alatt mind a négy csoportban paszszív szemlélőként voltunk jelen.

$\mathrm{Az}$ óvodapedagógusokkal készített interjúkat szintén 2020 januárjában, személyenként $\mathrm{kb}$. 30 perc alatt, hangfelvételre rögzítve vettük fel. Az interjúkat félig strukturált formában valósítottuk meg, így lehetőség volt a kötetlenebb beszélgetésre is.

\section{Eredmények}

Az óvodai zenei nevelés és képesség-fejlesztés megvalósulásával kapcsolatos e-redmények

$\mathrm{Az}$ óvodákban folyó zenei nevelés és képességfejlesztés helyzetének vizsgálatához először az óvodák pedagógiai programjainak zenei részeit tekintettük át. Elemzésünk során a tartalmi elemeket mind a négy program esetében rendben találtuk, zenei részeik teljes mértékben összhangban voltak az Óvodai nevelés országos alapprogramjában foglaltakkal.

A következőkben a pedagógiai programokban szereplő zenei nevelési elvek gyakorlatban történő megvalósulásának vizsgálatához az óvodák egy-egy csoportjának egy-egy „Ének, zene énekes játék, gyermektánc" tevékenységét figyeltük meg.

Az „A” óvodában az énekes tevékenység félig kötött szervezési formában, csoportos munkaforma keretében valósult meg. Tartalma nagyrészt megfelelt a gyermekek egyéni és életkori sajátosságainak, a dalok és mondókák szövege, hangterjedelme és ritmusképlete a korcsoport sajátosságainak megfelelő volt. Az egyes játékok, játékos gyakorlatok során az óvodapedagógus igyekezett a gyermekeket végig motivált állapotban tartani. A bemutatás, bemutattatás, magyarázat, beszélgetés, szemléltetés, ellenőrzés, ismétlés, hibajavítás, illetve a dicséret módszerét változatosan, az adott pedagógiai helyzetnek megfelelően alkalmazta, a tevékenység folyamán adódó spontán helyzeteket rugalmasan kezelte. Igyekezett figyelemmel kísérni a csoport éneklését, valamint a ritmusképzés gyakorlatainak megoldását, a feladatmegoldás közben előforduló hibákat azonban nem sikerült minden esetben észrevennie és javítania. A gyermekek ötleteit figyelembe vette, ezeket a tevékenység menetébe beillesztette. A zenés foglalkozás során törekedett a differenciálásra, a feladatok nehézségi fokát igye- 
kezett a gyermekek egyéni fejlettségi szintjéhez igazítani. A játékosság és a gyakorlatok képzelethelyzetbe történő ágyazása szinte mindig megvalósult. Az óvodapedagógus a tevékenység során az élő zenét részesítette előnyben; felkészültsége megfelelő volt, énekes előadása fejlesztette a gyermekek ízlését, elősegítette zenei fogékonyságuk alakulását.

A „B” óvodában az énekes tevékenység szervezeti formája kötött volt, a gyakorlatok megvalósítása frontális módon, többnyire csoportos munkaforma keretében történt. A tevékenység tervezése és kivitelezése során az óvodapedagógus a csoport már meglévő tapasztalataira épített; a gyakorlatokat igyekezett játékos formában, történetbe ágyazva megvalósítani. Próbálta a gyermekeket végig motivált állapotban tartani, de ez több esetben nem sikerült. A tevékenységre az élőzenével, a közös énekléssel, mondókázással szemben a gépi zene, az arra való mozgás és az azzal együtt való éneklés volt jellemző. A dal, mondóka, és zenehallgatási anyag kiválasztása nem minden esetben a gyermekeknek szánt zenés kötetek darabjai közül történt, az énekelt dalok hangterjedelme nem mindig felelt meg a gyermekek életkori sajátosságainak. A dinamikai különbség megfigyeltetése, felismertetése, összehasonlítása és megnevezése zene nélkül, csörgő hangot kiadó tojások megszólaltatásával, valamint az óvodapedagógus az átlagosnál halkabb vagy hangosabb beszéde segítségével történt. Ezeket a zene és dallam nélküli képességfejlesztő játékokat több gyermek hamar megunta, az egyik feladatot csak az óvodapedagógus határozottabb kérésére fejezték be. Kérdéseit az óvodapedagógus legtöbbször egyértelműen, a gyermekek anyanyelvi fejlettségének megfelelően tette fel; előfordult azonban, hogy utasításait nem értették meg. A bemutatás, bemutattatás, magyarázat, beszélgetés, szemléltetés, ellenőrzés, ismétlés, hibajavítás, illetve a dicséret módszerét változatosan, az adott pedagógiai helyzetnek megfelelően alkalmazta, a zenés foglalkozás során pedig a segítségnyújtásban mindig differenciált.

A „C” óvodában az énekes tevékenység félig kötött szervezési formában valósult meg. Tartalma (dal- és mondókaanyag, zenehallgatási anyag megválasztása; képességfejlesztés módszerei, gyakorlatai, játékai; eszközhasználat) minden tekintetben megfelelt a gyermekek egyéni és életkori sajátosságainak, zenei fejlettségének. Tervezése és kivitelezése során az óvodapedagógus a csoport már meglévő ismereteire épített; a hangulatában, illetve zeneileg és pedagógiailag is kerek egészet alkotó, jól átgondolt, tudatosan felépített tevékenységet játékos formában, történetbe ágyazva valósította meg. Felépítése a közvetíteni kívánt tartalomnak és a didaktikai feladatoknak megfelelő volt. A dalos, mondókás és képességfejlesztő játékokat az óvodapedagógus mindig az azok tartalmához és a didaktikai céljához leginkább illő munkaformában szervezte meg. Az egyes játékok, játékos gyakor- 
latok során a gyermekeket végig motivált állapotban tudta tartani. Állandó figyelemmel kísérte a csoport éneklését, valamint a ritmusképzés gyakorlatainak megoldását, az előforduló hibákat szóban, személyes példamutatással, esetenként a gyermekek mozgását irányítva igyekezett javítani. A bemutatás, bemutattatás, magyarázat, beszélgetés, ellenőrzés, ismétlés, hibajavítás, illetve a dicséret módszerét változatosan, mindig az adott pedagógiai helyzetnek megfelelően alkalmazta, a tevékenység folyamán adódó spontán helyzeteket rugalmasan kezelte. A zenés foglalkozás során végig differenciált, a feladatok nehézségi fokát minden esetben a gyermekek egyéni fejlettségi szintjéhez igazította. Az óvodapedagógus által kiválasztott igényes zenei anyag remekül fejlesztette a gyermekek ízlését, elősegítette zenei fogékonyságuk alakulását; a közös éneklés, a ritmushangszerek használata, a művészi értékű zenehallgatási darab meghallgatása pedig esztétikai és közösségi élményt nyújtott. A tevékenység során az óvodapedagógus az élő zenét részesítette előnyben.

A „D” óvodában az énekes tevékenység kötött szervezeti formában, frontális módon, csoportos munkaforma keretében valósult meg. A zenés foglalkozás tartalma dal- és mondókaanyag, valamint a zenehallgatási anyag megválasztása tekintetében teljes mértékben megfelelt a gyermekek egyéni és életkori sajátosságainak, zenei fejlettségének. A képességfejlesztés gyakorlatait az óvodapedagógus igyekezett a csoport számára változatos módszerek alkalmazásával vonzóvá tenni, de a történetbe ágyazás, az egyes mozdulatok játékos értelemmel való felruházása, a hangulatkeltés hiányzott a kivitelezésből. A játékok, játékos gyakorlatok során nem sikerült minden gyermeket végig motivált állapotban tartani, gyakori volt, hogy a ritmusképzés feladatai egyes gyermekek figyelmét nem kötötték le, azokat az érdeklődés hiányában az óvodapedagógus figyelmeztetése, bemutatása ellenére is nem, vagy csak unottan és helytelenül végezték. Magatartási problémák miatt néhány gyermeket az énekes játékok során többször kellett fegyelmezni, rendre inteni. A tevékenység tervezése és kivitelezése során az óvodapedagógus a csoport már meglévő ismereteire épített, kérdéseit mindig egyértelműen, a gyermekek anyanyelvi fejlettségének megfelelően tette fel. Állandó figyelemmel kísérte a csoport éneklését, a ritmusképzés gyakorlatainak megoldását, az előforduló hibákat szóban, vagy személyes példamutatással, a gyermek mozgását irányítva igyekezett javítani. A bemutatás, bemutattatás, magyarázat, beszélgetés, ellenőrzés, ismétlés, hibajavítás és a dicséret módszerét változatosan, az adott pedagógiai helyzetnek megfelelően alkalmazta. Az óvodapedagógus által kiválasztott igényes zenei anyag jól fejlesztette a gyermekek ízlését, elősegítette zenei fogékonyságuk alakulását; a közös éneklés, a ritmushangszerek használata, a művészi értékű zenedarab meghallgatása pedig esztétikai és közös- 
ségi élményt nyújtott az óvodások számára. A tevékenység során az óvodapedagógus az élő zenét részesítette előnyben.

A későbbiekben az óvodapedagógusokat egy interjú keretében is megkérdeztük arról, hogy mik azok a legfőbb módszertani alapelvek és szabályok, melyeket az „Ének, zene, énekes játék, gyermektánc" tevékenységek tervezése és megvalósítása során figyelembe vesznek. A válaszokból egyöntetűen kiderült, hogy a zenei tevékenységek szervezéséhez az alapot mind a négy helyen Kodály Zoltán és Forrai Katalin zenei nevelési elvei jelentik. Láthattuk továbbá azt is, hogy a térség egyes óvodapedagógusai még mindig ragaszkodnak a régi módszerekhez, egyes intézményekben pedig a tevékenységek is kötelező jelleggel zajlanak.

$\mathrm{Az}$ énekes tevékenységek anyagának, céljának, menetének előzetes megtervezését valamennyi interjúalanyunk fontosnak tartja. Az éves tervet az óvodapedagógusok mind a négy csoportban előzetesen elkészítik, az egyes ének-zenei tevékenységek anyagát és menetét pedig általában témaheteik, projektjeik tartalmához igazítva tervezik. Az óvodapedagógusok azt is elmondták, hogy a gyermekek zenei ízlésében és szociokulturális hátterében jelentkező eltérések nagyban megnehezítik a tervezéssel és kivitelezéssel kapcsolatos feladataikat.

Interjúalanyainkat arról is megkérdeztük, hogy milyen szervezési módban valósítják meg legtöbbször a gyermekek zenei élményszerzését. A válaszokból kiderült, hogy a kötött, kötetlen, illetve spontán tevékenységek mind a négy csoportban egyaránt jelen vannak egymás kiegészítőjeként, megfigyelhető azonban az is, hogy ezek prioritása, illetve tartalma óvodánként és csoportonként eltérő. Kiderült, hogy az egyik óvodában a legnagyobb szerepet és a legtöbb fejlesztő hatást a kötött formájú foglalkozásoknak tulajdonítják, míg a másik három településen az óvodapedagógusok - a különféle szervezési módok eltérő célja és jótékony hatása miatt - a három forma egyenlő mértékű fontosságát hangsúlyozzák. A tevékenységeket - azok jellegétől függően - az óvodák egyaránt csoportos vagy mikrocsoportos formában valósítják meg, a sokszor igen eltérő egyéni képességekkel rendelkező gyermekek énekes tevékenységeken való egyidejű fejlesztését pedig a differenciálás és a didaktikai módszerek egyéni és életkori sajátosságokhoz való igazításával igyekeznek megoldani. Az óvodapedagógusok nagy szerepet tulajdonítanak az egyéni képességfejlesztésnek is, ezt igyekeznek már minél fiatalabb korban megvalósítani.

Kíváncsiak voltunk arra is, hogy az óvodapedagógusok milyen forrásokból választják az ének-zene tevékenységeken használt zenei darabokat, illetve, milyen szempontokat vesznek figyelembe a gyermekeknek tanítandó dalanyag, és zenehallgatásra szánt anyag kiválasztása során. A válaszokból láthattuk, hogy a zenei forrásanyagot az óvodapedagógusok mind 
a négy helyen legtöbbször Forrai Katalin: Ének az óvodában, illetve Törzsök Béla: Zenehallgatás az óvodában c. könyvéből választják, emellett pedig a „C” óvodában megjelennek a különféle komolyzenei hanganyagok, illetve Gryllus Vilmos kazettái, a „D” és „A” óvodában pedig előkerülnek a modern, interneten elérhető, a gyermekek által otthon is sokat hallgatott dalok (pl.: Zeneovi) is.

Az elmondottakból azt is megtudtuk, hogy az óvodapedagógusok a gyermekeknek tanítandó dalanyag kiválasztásakor jellemzően mind a négy helyen figyelembe veszik a gyermekek életkori sajátosságait, képességeit, előzetes ismereteit, valamint a tanítandó dalok hangterjedelmét, szövegösszetételét és hosszúságát. A dalanyag főként magyar gyermekdalokból és népdalokból tevődik össze, „D” óvoda óvodapedagógusa azonban kikerülhetetlennek tartja a gyermekek által kedvelt, otthon is gyakran hallgatott „fülbemászó” műdalokat is. A zenehallgatásra szánt dalok közt is általában a magyar népdalok és gyermekdalok dominálnak, mellettük pedig kisebb százalékban a műdalok és a klasszikus zenei darabok is előfordulnak ez azonban egyes csoportokban nem köti le a gyermekek figyelmét. Az etnikai kisebbség dalait - annak ellenére, hogy a nemzetiségi hovatartozás figyelembevétele három óvoda pedagógiai programjában is szerepelt - csak „A” óvodában építik be valamilyen szinten a zenei tevékenységek zenehallgatási részeibe, a többi óvodapedagógust erről kérdezve minden esetben a nem választ kaptuk. Az etnikai közösség hagyományainak, zenei kultúrájának tevékenységekbe való beépítése szintén egyik intézményre sem jellemző, helyette a magyar hagyományokat részesítik előnyben.

\section{A gyermekek óvodai és otthoni}

zenei tevékenységére vonatkozó eredmények.

Interjúnkból, az óvodapedagógusokat a gyermekek énekes tevékenységekhez való viszonyáról kérdezve kiderült, hogy a gyermekek szívesen és gyakran kezdeményeznek ilyen jellegű tevékenységeket, és örömmel vesznek részt az óvodapedagógus által kezdeményezett közös énekes-zenés tevékenységekben is. Megtudtuk továbbá, hogy a gyermekeknek az óvodába kerüléskor még nem feltétlenül van igényük a közös éneklésre, a zenélési kedv csak fokozatosan alakul ki náluk; a későbbiekben viszont a zenei tevékenységek iránt nagyon érdeklődővé és könnyen motiválhatóvá válnak.

A szülőket kérdőívünkben az óvodai zenei nevelés gyermekekre gyakorolt hatásáról kérdezve láthattuk, hogy a gyermekek 84,8\%-a többet énekel otthon, mióta óvodába jár; „Elújságolja-e gyermeke otthon, ha új dalt vagy mondókát tanulnak az óvodában?” kérdésünkre érkezett válaszaikból pedig megtudtuk, hogy a gyermekek 79,7\%-a elújságolja és szívesen el is énekli/mondja otthon az óvodában tanult dalokat/mondókákat, míg további 8,7\%-a csak elújságolja ezeket. 


\section{Zenei képességeket, érdeklódést és fejlódést} befolyásoló háttértényezőlkre utaló eredmények

Kutatásunk egy része kitért a gyermekek zene iránti érdeklődését, valamint zenei képességeik, készségeik fejlődésének idejét és tempóját befolyásoló háttértényezőkre. Interjúnkból kiderült, hogy az óvodákba érkező gyermekek etnikai összetétele, anyagi és szociokulturális háttere igen vegyes. Magas a hátrányos és halmozottan hátrányos helyzetű gyermekek száma, és a mélyszegénységben élők aránya is növekszik. A gyermekek egy részének hátterére továbbá az ingerszegény otthoni környezet is jellemző. Az óvodapedagógusokat a gyermekek zenei érdeklődésének alakulásáról kérdezve kiderült, hogy bár az előbb felsorolt tényezők függvényében gyakran tapasztalnak eltéréseket a gyermekek zenei preferenciájában, a zenei ízlés romlását általánosságban az összes gyermeknél megfigyelik. Megfigyelhető, hogy zenei érdeklődésük egyre inkább a modern könnyűzene (pl.: Nótár Mary, L.L. Junior) és a napjainkban egyre inkább elterjedt televíziós tehetségkutató mûsorok zenéi felé fordul, és már az óvodásoknál is egyre gyakoribbá válik az IKT eszközök és az azokon elérhető zenés applikációk (TikTok, YouTube) egyre fiatalabb korban való használata; a magyar népdalokat, ölbeli játékokat pedig nem igazán ismerik.

Az óvodapedagógusokat a következőkben arról is megkérdeztük, hogy tapasztalnak-e valamilyen eltérést a különböző etnikumú, szociokulturális helyzetű, illetve a magasabb és alacsonyabb iskolai végzettséggel rendelkező szülők gyermekeinek zenei érdeklődésében, zenei képességeinek, készségeinek fejlődési idejében, tempójában. Az óvodapedagógusok elmondták, hogy meglátásuk szerint a gyermekek zenei érdeklődésének alakulására mindhárom felsorolt tényező hatással van, a zenei képességek fejlődési idejében és tempójában azonban a szülők iskolai végzettsége szerint nem tapasztalnak különbséget. Általánosságban megfogalmazták, hogy a roma gyerekek sokkal bátrabbak, tisztán énekelnek, nagyon jó a hallásuk és a ritmusérzékük, szeretnek táncolni és könnyen bevonhatók az énekes tevékenységekbe; a jobb szociokulturális helyzetú, általában magasabb iskolai végzettséggel rendelkező szülők gyermekeiről pedig kiderült, hogy többségében jobb zenei háttérrel rendelkeznek és ebből kifolyólag sokkal inkább fogékonyak az igényes zenehallgatási anyagokra.

A sqülók iskolai végzettségének hatása az óvodás korú gyermekük zenei nevelésével kapcsolatos attitüdjeikere

Szülői kérdőívünket 76 alacsonyabb $(55,1 \%)$ és 62 magasabb (44,9\%) iskolai végzettséggel rendelkező személy töltötte ki (lásd: 1. ábra). A kitöltők 50,7\%-a hamar, már magzati korban, 19,6\%-a csecsemőkorban, 10,9\%-a gyermeke első szavainak megjelenésétől, 10,1\%-a pedig gyermeke óvodába kerülésétől elkezdte gyer- 
1. ábra: Az iskolai végzettségek megoszlása (forrás: a Szerző)

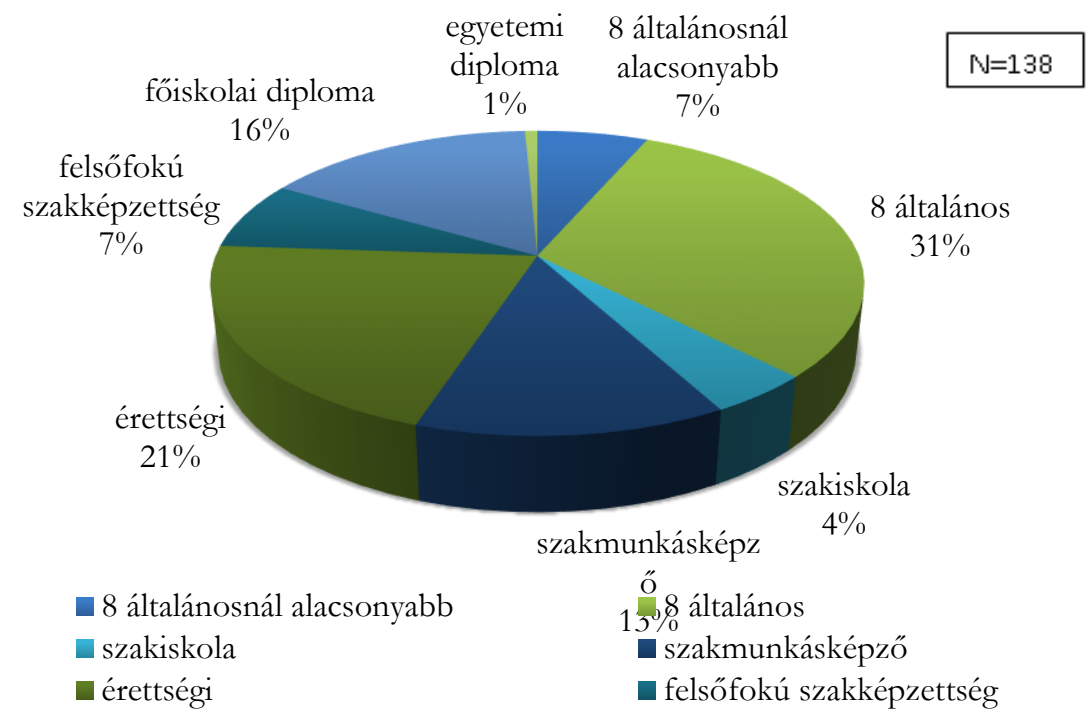

meke zenei nevelését; 8,7\%-a viszont portjainál az erre a kérdésre adott válagyermeke zenei fejlesztését egyáltalán nem kezdte el. Megfigyelhető, hogy a maszaik esetében nem mutatkozott meg szignifikánsan nagyobb eltérés (ANOVA gasabb iskolai végzettséggel rendelkező szülők 88,7\%-a már korán elkezdte gyermeke zenei nevelését, és egy olyan sincs köztük, aki gyermeke óvodás koráig ezt egyáltalán ne tette volna meg, ellentétben az alacsonyabb iskolai végzettségü szülőkkel, akiknek csak 38,2\%-a kezdte el gyermeke zenei nevelését magzati korban.

Elmondható, hogy a kitöltôk 84,1\%-ának családjában fontos szerepet tölt be a zene, és mindössze 15,9\%-a tartja ezt elhanyagolhatónak. A magasabb és alacsonyabb iskolai végzettségű személyek cso$\mathrm{p}=0,391, \mathrm{~F}=1,064)$.

Zenét mind a magasabb (96,7\%), mind az alacsonyabb (94,2\%) iskolai végzettséggel rendelkező szülők családjában közel azonos százalékban hallgatnak, jelentős különbségek figyelhetők azonban meg a két csoport zenei ízlésében (lásd: 2. ábra). Látható, hogy a komolyzenét hallgatók aránya a magasabb iskolai végzettséggel rendelkező személyek közt 7\%kal magasabb, mint az alacsonyabb iskolai végzettségű személyek csoportjában. A népzene esetében ez az arány már 15,1\%- 
1. ábra: A családok zenei preferenciája (forrás: a Sžerzőo)

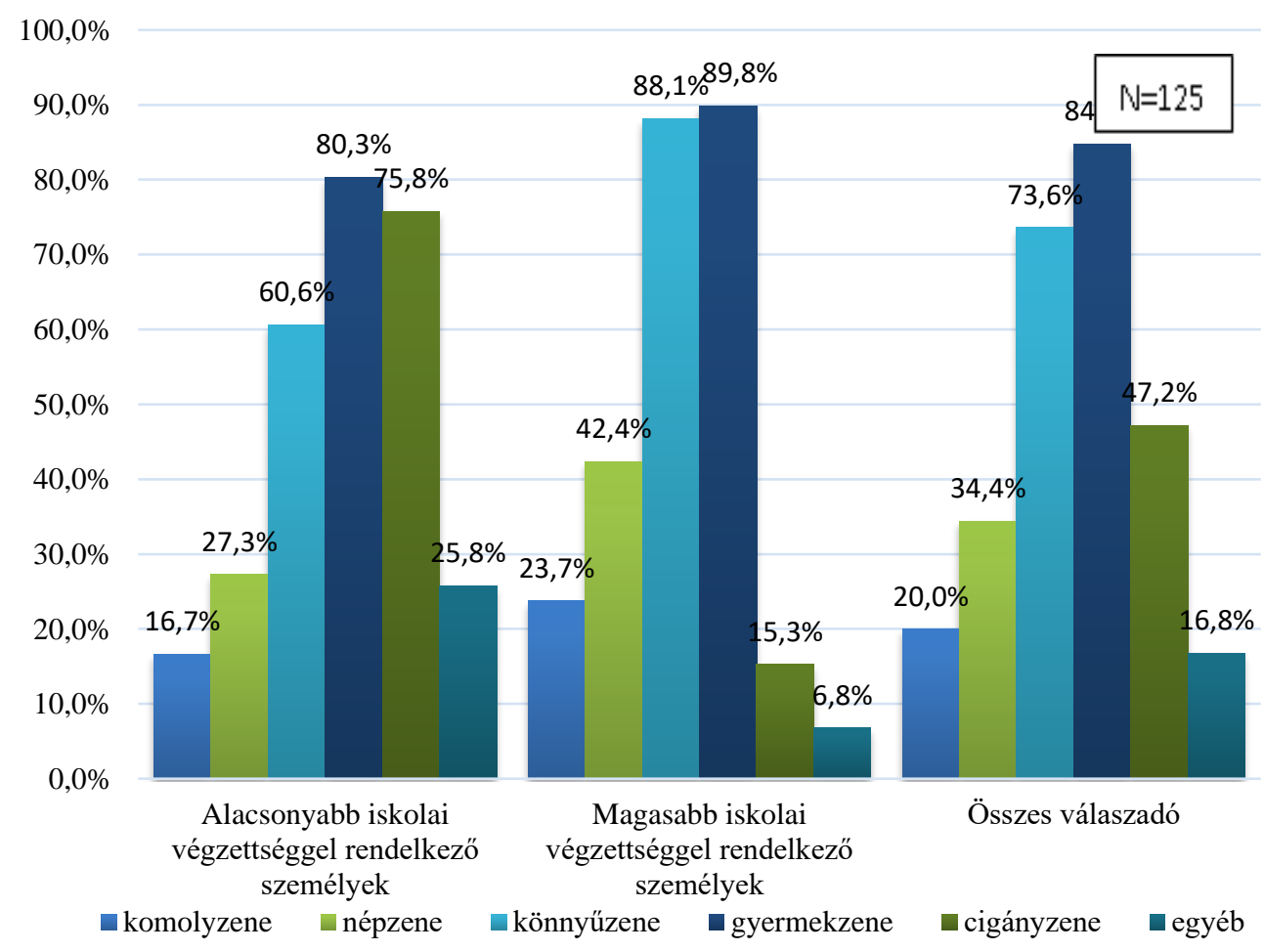

kal, a könnyüzenénél 27,5\%-kal, a gyermekzene esetében pedig 9,5\%-kal nagyobb, szintén a magasabb iskolai végzettségű személyek javára. Nagy különbséget tapasztalhatunk a két csoport közt a cigányzenét hallgató személyek arányát tekintve is. Ez esetben megfigyelhető, hogy az alacsonyabb iskolai végzettséggel rendelkező személyek közül sokkal - százalékos arányt nézve $60,5 \%$-kal - többen hallgatnak cigányzenét, mint a magasabb iskolai végzettséggel rendelkező személyek.
A 2. ábrán felsorolt zenei műfajok gyermekekre gyakorolt hatását vizsgálva öszszefüggést feltételezhetünk a családok zenei preferenciája, az általuk kedvelt, gyakran hallgatott zenei műfajok és a gyermekek zenei ízlése közt. Megfigyelhető ugyanis, hogy az otthonukban általában több könnyűzenét hallgató, magasabb iskolai végzettségű szülők gyermekei sokkal nagyobb arányban mutatnak fogékonyságot erre a múfajra, mint a kevesebb ilyen típusú zenét hallgató alacsonyabb iskolai végzettséggel rendelkező 
szülők gyermekei; és ugyanez igaz a cigányzene esetében is fordítva.

Kiderült, hogy a gyermekek legtöbbje elsősorban a szüleivel való közös éneklés $(87,7 \%)$ és a televízióban látott zenés müsorok $(68,8 \%)$ útján találkozik a zenével. $56,5 \%$ szokott valamely rokonnal (pl.: nagyszülővel vagy testvérrel) közösen énekelni; 43,5\% hallgat zenét rádióban; 34,8\% látogat gyermekeknek szóló zenés műsorokat, koncerteket; 29,7\% hallgat zenét CD-lejátszón és 14,5\% látogat gyermekeknek szóló népi, táncos programokat. A válaszokat megfigyelve látható az is, hogy a gyermekek mindössze 12,3\%-a (szám szerint 17 gyermek) szokta szülei vagy más rokona hangszerjátékát hallgatni, holott kiderült, hogy a válaszadók családtagjai közül 53-man tudnak hangszeren játszani. A gyermekek zenével való találkozásának módjában legkisebb arányban a lemezlejátszó hallgatása (5,8\%) és a komolyzenei hangversenyek látogatása $(2,2 \%)$ van jelen. A magasabb és alacsonyabb iskolai végzettségü személyek csoportjait nézve a gyermekek zenével való találkozásának módjában is megfigyelhetők eltérések. A magasabb iskolai végzettséggel rendelkező szülők gyermekei közül pl.: 26,5\%-kal hallgatnak többen rádión, és 10,5\%-kal hallgatnak többen CD lejátszón zenét, mint az alacsonyabb iskolai végzettségű szülők gyermekei, de a gyermekeknek szóló zenés műsorokat is 39,4\%-kal, illetve a gyermekeknek szóló népi jellegű, táncos programokat is 11,8\%-kal több magasabb iskolai végzettségű szülő keresi föl gyermekével.

A közös együtténeklési szokásokat nézve látható, hogy a szülők 86,1\%-a szokott gyermekének énekelni. A gyermeküknek éneklő és nem éneklő szülők aránya a két eltérő iskolai végzettségű csoportban eltérően alakul. Míg a magasabb iskolai végzettségű személyek csoportjában az éneklő és nem éneklő szülők aránya 98,4\% és $1,6 \%$, addig az alacsonyabb végzettséggel rendelkező szülőknél ez $76 \%$ és $24 \%$. A gyermeküknek nem éneklő szülők a közös éneklést általában a rossz hangjuk miatt mellőzik.

A gyermekeknek szánt dalok típusát nézve kiderült, hogy a szülők 85,7\%-a szokott gyermekének kis hangterjedelmű, az óvodás korosztály zenei képességeinek megfelelő gyermekdalokat énekelni, emellett pedig 44,5\% magyar könnyűzenei dalokat, 42\% népdalokat, 20,2\% külföldi, idegen nyelvű dalokat is énekel gyermekének. Arányokat tekintve a magasabb iskolai végzettséggel rendelkező szülők közül 19,2\%-kal többen szoktak gyermeküknek kis hangterjedelmű gyermekdalokat, 24,8\%-kal többen pedig népdalokat énekelni, mint az alacsonyabb iskolai végzettségű személyek. Megfigyelhető továbbá, hogy a közös éneklés során a magyar könnyűzenei dalok szintén a magasabb iskolai végzettséggel rendelkező családokban fordulnak elő nagyobb arányban, a külföldi, idegen nyelvű dalokat viszont az alacsonyabb iskolai végzettséggel rendel- 
kező szülők éneklik gyermekeiknek magasabb, 11,1\%-kal nagyobb arányban.

Megállapítható, hogy a legtöbb szülő $(73,7 \%)$ a gyermekével való közös játék közben szokott énekelni gyermekének, de gyakori, hogy erre a közösen végzett házimunka $(53,4 \%)$, utazás, séta vagy kirándulás (49,2\%) közben, elalvás előtt (40,7\%), vagy a gyermek rossz kedve $(34,7 \%)$, vagy unatkozása $(24,6 \%)$ esetén kerül sor.

Elmondható, hogy különféle zenélő, hangeffektekkel ellátott játékokkal a gyermekek 77\%-a, boltban vásárolt játékhangszerekkel 67,5\%-a, szülőkkel közösen készített játékhangszerrel pedig 20,6\%-a rendelkezik otthonában és csupán 8 gyermek van, aki a felsorolt játéktípusok közül egyik fajtával sem rendelkezik. A magasabb és alacsonyabb iskolai végzettségű személyek csoportjait megnézve megfigyelhetjük, hogy a magasabb iskolai végzettségű szülők gyermekei közül 27,4\%-kal többen rendelkeznek boltban vásárolt játékhangszerekkel, 8,2\%-kal többjüknek vannak otthon zenélő, különféle hangeffektekkel ellátott játékai és 27,1\%-kal többen szoktak közülük szüleikkel közösen játékhangszereket készíteni, mint az alacsonyabb iskolai végzettségű szülők gyermekei.

Utolsó kérdésünkben a szülőket a zenei nevelés zenei és nem zenei képességeket fejlesztő hatásairól kérdezve láthatjuk, hogy még a magasabb iskolai végzettséggel rendelkező szülők is csak kevésbé vannak tisztában a zenei nevelés transzferhatásaival (lásd: 3. ábra).

2. ábra: A szülök véleménye a zuenei nevelés fejlesztő hatásairól (forrás: a Szerző)

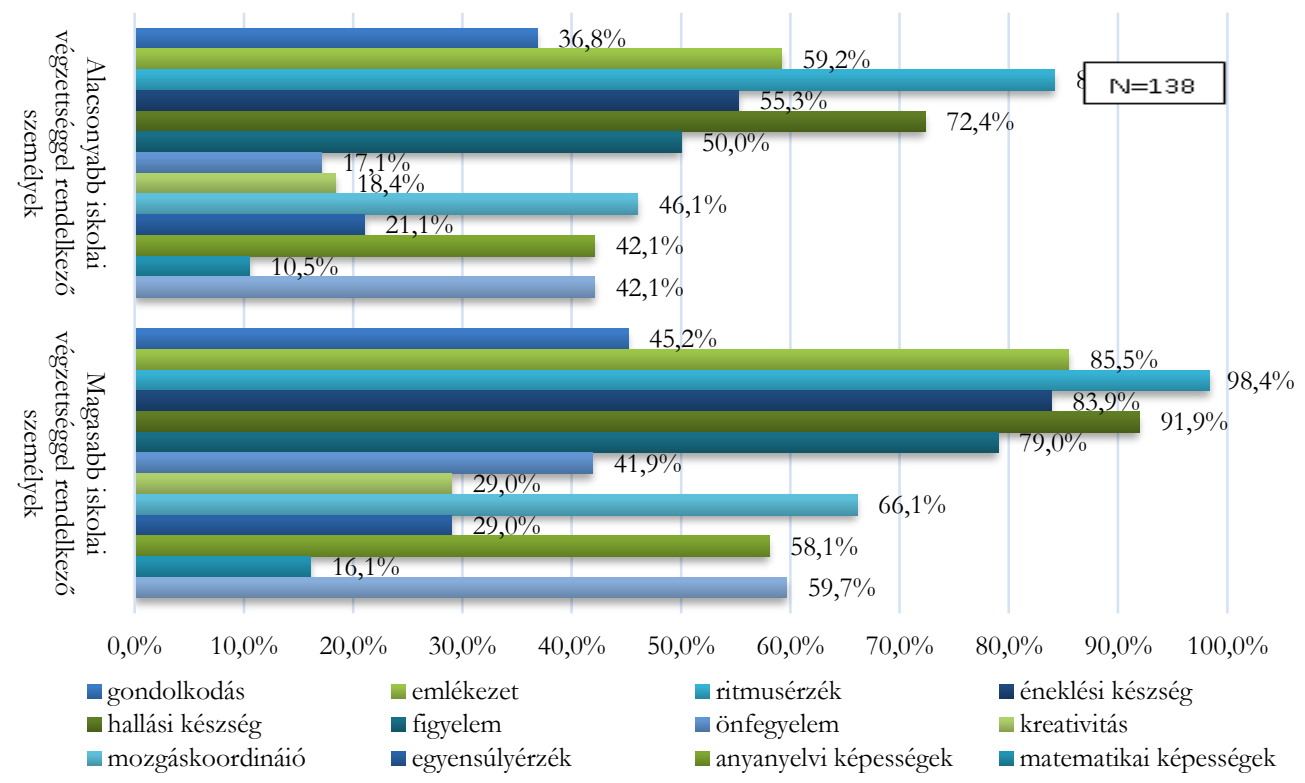


A szülók és az óvodapedagógusok körötti, zenei nevelést érintö kapcsolatra vonatkozó eredmények

A szülők és az óvodapedagógusok közötti, a zenei nevelés terén történő kapcsolattartást két oldalról, az óvodapedagógusok és a szülők szemszögéből is megvizsgáltuk.

A szülők részéről szerettük volna megtudni, hogy hányan vannak köztük, akik tudják, mely napokon van gyermekük csoportjában az ének-zenei tevékenység, illetve, hogy kapnak-e valamilyen tájékoztatást gyermekük óvodapedagógusától a csoportban éppen aktuális dal- és mondókaanyagról. Szülői kérdőívünkből kiderült, hogy a szülők 72,3\%-a - alacsonyabb iskolai végzettségű szülők 80,3\%, magasabb iskolai végzettségű szülők 62,3\% nem tudja mely napon van gyermeke csoportjában az „Ének, zene, énekes játék, gyermektánc” tevékenység, 48,1\%-a pedig semmiféle tájékoztatást nem kap gyermeke óvodapedagógusától a csoportban éppen aktuális dal- és mondókaanyagról. A kérdésekre érkezett válaszokból láthattuk azt is, hogy a szülők 32,6\%-a szokott érdeklődni gyermeke óvodapedagógusánál, hogy gyermeke rész vesz-e az énekes tevékenységeken, 29,4\%a kérdez rá, hogy gyermeke érdeklődik-e az ének-zenei tevékenységek iránt, valamint $16,7 \%$-a arra is kíváncsi, hogy gyermeke zenei képességei milyen mértékben fejlődtek.

Interjúnkban az óvodapedagógusokat ugyanezekről kérdezve kiderült, hogy az aktuális dal- és mondókaanyagról csak egy óvoda tájékoztatja rendszeresen a szülőket - itt az aktuális dalanyagot az óvodapedagógusok hirdetőtáblára teszik fel -, a többi helyen érdeklődés hiányában ez már évek óta elmarad. Az óvodapedagógusok elmondása szerint továbbá egyik településen sem jellemző, hogy a szülők bármilyen, a gyermekük zenei fejlődésével vagy fejlesztésével kapcsolatos kérdésekkel fordulnának hozzájuk. Szülőkkel közös zenés rendezvények mind a négy óvodában vannak, de ezek kimerülnek a gyermekek anyák napi, farsangi vagy más ünnepi műsorainak megtekintésében. Olyan jellegű programokra, ahol a szülők megismerhetnék a zenei fejlesztés elveit, módszereit, vagy gyermekeikkel közösen egy-egy délutáni zenés foglalkozáson vehetnének részt egyik településen sincs lehetőség, és az óvodapedagógusok szerint a szülők ezt egyáltalán nem is igénylik.

\section{Értékelés}

Az óvodák pedagógiai programjainak tanulmányozása során láthattuk, hogy kidolgozásuk és tartalmuk minden intézmény esetében az Óvodai Nevelés Országos Alapprogramjának megfelelő, megfigyeléseink és az óvodapedagógusokkal készített interjúink során azonban több esetben is ellentmondások és hiányosságok derültek ki. Két helyen az énekes tevékenységek kötött formában, frontális munkaforma keretében valósulnak meg, a képességfejlesztő részek pedig ezen a két 
helyen több esetben is a differenciálás, vagy a játékosság módszerének hiányos alkalmazása mellett a tevékenység közben jelentkező holt idő kitöltése nélkül, nem minden esetben a megfelelő didaktikai módszerek megválasztása mellett zajlanak. Esetenként problémát jelentett a zenehallgatási anyag megválasztása, jellemző volt a gépi zene túlsúlya, illetve előfordult, hogy a dalok hangterjedelme sem volt megfelelő. Habár az óvodák pedagógiai programjában szerepelt, az etnikai kisebbség zenéjét csak egy intézményben építik be valamilyen szinten a zenei nevelés mindennapjaiba. A megfelelő, élményt nyújtó zenei nevelés csak egy helyen valósult meg teljes mértékben.

A szülői kérdőívek elemzéséből kiderült, hogy a gyermekek 84,8\%-a többet énekel otthon mióta óvodába jár, 79,7\%-a pedig elújságolja és szívesen el is énekli otthon az óvodában tanult dalokat. Megállapítható tehát, hogy az óvodai zenei nevelés feltételezésünknek megfelelően nagy hatást gyakorol a gyermekekre ez azonban azokra az óvodákra is igaz, ahol a zenei nevelés nem megfelelő módon valósul meg, a zenei nevelés minőségének függvényében ugyanis nem tapasztaltunk szignifikáns eltérés a gyermekek otthoni éneklési kedvében (ANOVA $\mathrm{p}=0,106$ $\mathrm{F}=2,080)$.

A gyermekek zene iránti érdeklődését, valamint zenei képességeik, készségeik fejlődésének idejét és tempóját vizsgálva láthattuk, hogy a zenei ízlés és a zenei képességek alakulásában a szociokulturális háttérnek döntő szerepe van. Az óvodapedagógusok elmondása szerint a magasabb iskolai végzettséggel rendelkező szülők gyermekei a jobb otthoni zenei és szociokulturális háttérnek köszönhetően fogékonyabbak az igényes zenehallgatási anyagokra, és jobban megragadja figyelmüket a hangszerjáték. Szintén az ideálisabb családi háttérnek és a gyermekekre jutó nagyobb figyelemnek köszönhetően elmondható, hogy ezek a gyermekek általában jobb zenei alapokkal rendelkeznek, érdeklődőbbek az óvodai zenei tevékenységek iránt és nagyobb figyelemmel követik azok menetét, mint a rosszabb körülmények közül érkező társaik. A magyar és roma etnikumú gyermekek képességeit nézve kiderült, hogy a térség óvodáiba járó roma gyermekek általában jobb ritmusérzékkel és zenei hallással rendelkeznek, előfordul viszont, hogy zenei képességeik fejlődése - a nem megfelelő családi háttér miatt - mégis lassabb. Zene iránti érdeklődésük nagyobb, de ez a lelkesedés főként az otthon hallott zenei anyagokra, a különféle könnyűzenei műfajokra, a cigányzenére, a lakodalmas és mulatós zenére, illetve a televíziós tehetségkutató műsorokra és az aktuális sztárok zenéjére irányul. A magyar népdalokat, ölbeli játékokat nem igazán ismerik, ezáltal pedig sokkal kevésbé fogékonyak az igényes zenei anyagokra, mint a jobb szociokulturális környezetből érkező társaik. Elmondható azonban, hogy viszonylag könnyen bevonhatók a különféle zenés tevékenységekbe, az ének- 
zene területén pedig jellemzően bátrabbak és pozitív értelemben gátlástalanabbak, mint magyar etnikumú társaik.

A családokban folyó zenei nevelést vizsgálva láthattuk, hogy a zenét mind a magasabb, mind az alacsonyabb iskolai végzettségű szülők közel azonosan nagy százaléka $(86,7 \%, 81,9 \%)$ tartja fontosnak családja életében; a gyermekeik zenei nevelését viszont a magasabb végzettséggel rendelkező szülők szignifikánsan hamarabb elkezdték (ANOVA $\mathrm{p}=0,005 \mathrm{~F}=$ 3,080), mint alacsonyabb végzettséggel rendelkező társaik. Kiderült továbbá, hogy a magasabb iskolai végzettségű szülők sokkal inkább tisztában vannak a zenei nevelés zenei képességeket fejlesztő és transzfer hatásaival; többen érdeklődnek közülük óvodapedagógusuknál gyermekeik zenei képességeinek fejlődéséről, vagy az óvodai zenei tevékenységeken mutatott aktivitásukról, és nagyobb arányban tudják, hogy mikor van gyermekeik csoportjában az „Ének, zene, énekes játék, gyermektánc" tevékenység (ANOVA $\mathrm{p}<0,000, \mathrm{~F}=4,599)$, mint az alacsonyabb végzettséggel rendelkező társaik. Nagyobb részük hallgat gyermekeivel minőségi, a 3-7 éves korosztály életkori sajátosságainak megfelelő zenei alkotást, gyakrabban látogatnak gyermekeikkel zenés rendezvényeket, és nagyobb arányban vásárolnak nekik különféle játékhangszert. Kérdőíves adatainkból kiderült az is, hogy a magasabb iskolai végzettségű szülők közül jelentősen többen szoktak gyermekeiknek énekelni (ANOVA p<0,000, F =
4,213), azonban a gyermekeknek szánt dalanyagba még az ő esetükben is többször belekeverednek a különféle könnyúzenei darabok, illetve a külföldi, idegen nyelvű dalok. Elmondható azonban, hogy kis hangterjedelmú gyermekdalokat az alacsonyabb iskolai végzettségű szülők $75,9 \%$-a is szokott énekelni gyermekének. Bár látható, hogy a 3-7 éves korosztály életkori sajátosságainak megfelelő zenét szinte minden családban hallgatnak $(84,8 \%)$, mégis mind a magasabb, mind az alacsonyabb iskolai végzettséggel rendelkező szülők családjaiban jellemző, hogy az óvodások a televízióban, a rádióban sok igénytelen zenei anyaggal is találkoznak. A magasabb iskolai végzettséggel rendelkező szülők családjainak 88\%-ára is jellemző, hogy gyermekükkel közösen könnyűzenei dalokat hallgatnak; az igényes komolyzenei darabok lejátszása azonban az ô körükben is viszonylag alacsony $(23,7 \%)$. Láthatjuk tehát, hogy a szülők érzik a zenei nevelés fontosságát és ennek megfelelően próbálják tudatosan nevelni gyermekeiket, sok esetben azonban még a gyermekeiknek tudatosan jobb zenei hátteret biztosító magasabb iskolai végzettséggel rendelkező szülők sincsenek tisztában ennek helyes módszereivel.

A szülők és az óvodapedagógusok közötti, a zenei nevelés terén történő kapcsolattartást vizsgálva kétoldalú problémát fedeztünk fel. Szülői kérdőívünkből kiderült, hogy a szülők 72\%-a nem tudja mely napon van az énekes tevékenység gyermeke csoportjában, 50\%-a pedig semmi- 
féle tájékoztatást nem kap gyermeke óvodapedagógusától az éppen aktuális dal- és mondókaanyagról. Az adatok összesítéséből kiderült az is, hogy a szülők viszonylag nagy része, 70\%-a azonban szokott gyermeke óvodapedagógusához a gyermeke zenei nevelésével kapcsolatos kérdésekkel fordulni. Az óvodapedagógusok azonban más véleménnyel vannak errôl a kérdésrôl. Szerintük a szülők nem érdeklődőek és nem is igénylik a zenei neveléssel kapcsolatos közös programokat, illetve tájékoztatókat. A térség óvodáiban ezért nyíltnapok, és ilyen jellegű programok nincsenek; a heti aktuális dalés mondókaanyag is csak egy óvodában érhető el egyöntetűen minden szülő számára, a többi helyen a csekély számú érdeklődőre hivatkozva ilyen jellegü tájékoztató nem kerül kihelyezésre. A kapcsolattartás e téren fôként csak az óvodai ünnepségek keretében történik meg, így megállapítható, hogy a kapcsolattartás terén a különféle kezdeményezések ellenére még mindkét fél részéről erőfeszítéseket célszerû tenni.

\section{Konklúziók}

Összegzésként elmondható, hogy a többféle kutatási módszer alkalmazásával lehetőségünk nyílt a tények mögött mélyebben meghúzódó ok-okozati összefüggések megismerésére.

$\mathrm{Az}$ eredményeket tekintve újra beigazolódott Kodály azon feltevése, miszerint a gyermek 3-7 éves kora között szerzett tapasztalatai egész életre szólóak, meghatározzák a gyermek későbbi zenei ízlését. Láthatóvá vált továbbá, hogy az otthoni zenei környezet által befolyásolt zenei ízlés már kis, 3-4 éves korban is erősen megmutatkozik, a negatív irányba befolyásolt zenei érdeklődés pedig nagyban megnehezíti az óvodákban a megfelelő zenei nevelés feltételeinek kialakítását. Helytelen attitűd azonban az óvodapedagógusok részéről, hogy a gyermekek által hozott rossz zenei anyagra és a szülők nemtörődömségére hivatkozva feladják a zenei nevelés helyes, szakszerű megvalósítását, holott láthattuk, hogy két óvodában ugyanilyen körülmények között a helyes módszerek alkalmazásával kitűnő eredményeket érnek el. Egyértelmű azonban, hogy a változásnak nem csak az óvodákban kell megtörténni. Ahhoz, hogy a gyermekek zenei nevelése időben és megfelelő anyagokkal kezdődhessen el, elengedhetetlen lenne a szülők ismereteinek bővítése is, ehhez viszont olyan, direkt erre a célra szervezett programokra lenne szükség, ahol a szülők megismerkedhetnek a gyermek életkorának megfelelő dalokkal, mondókákkal, a zenei képességek fejlesztésének otthon is egyszerűen megvalósítható formáival, és segítséget kaphatnak a napjainkban forgalomban lévő, igen sokszínű zenei kiadványok közötti válogatáshoz. Ehhez természetesen az óvodák felelősségvállalására, kitartó munkájára, segítségnyújtására van szükség. 


\section{Irodalom}

Barkóczi, I. és Pléh, Cs. (1977). Kodály zenei nevelési módszerének pszichológiai hatásvizsgálata. Kodály Zoltán Zenepedagógiai Intézet - Bács megyei Lapkiadó Vállalat, Kecskemét.

Forrai, K. (2016). Ének az óvodában. Móra Könyvkiadó, Debrecen.

Gévayné Janurik, M. (2010). A zenei hallási képességek fejlödése és összefüggése nébány alapkészséggel 4-8 éves kor között. $\mathrm{PhD}$ értekezés. Szegedi Tudományegyetem, Bölcsészettudományi Kar, Neveléstudományi Doktori Iskola, Szeged. Letöltés: 2019.11.24. Web: http://www.edu.uszeged.hu/phd/do wnloads/gevayne_janurik_ertekezes.p df

Harmat, L. (2005). Növel-nevel a zene. In: Balázsné Szűcs, J. (Ed.) Nevelés ötlet(l)esen. SZORT Bt. OVIZUÁL Kreatív Múhely, Budapest. 93-112.

Janurik, M. (2008). A zenei képességek szerepe az olvasás elsajátításában. Magyar Pedagógia, 108, 289-317.

Janurik, M. és Józsa, K. (2013). A zenei képességek fejlődése 4 és 8 éves kor között. Magyar Pedagógia, 113, 75-99.

Kodály, Z. (1982). Visszatekintés I. Zeneműkiadó, Budapest.
Kokas, K. (1972). Képességfejlesztés zenei neveléssel. Zenemúkiadó, Budapest.

Net1: UQ News. (2015). Jamming with toddlers trumps hitting the books. Letöltés: 2019.08.17. Web: https://www.uq.edu.au/news/article/ 2015/09/jamming-toddlers-trumpshitting-books

Net2: 363/2012. (XII. 17.) Korm. rendelet az Óvodai nevelés országos alapprogramjáról. Letöltés: 2019.10.22. Web:

https:// net.jogtar.hu/jogszabaly?docid $=\mathrm{a} 1200363 . \mathrm{kor}$

Rauscher, F. H. (2003). Can music instruction affect children's cognitíve development? Eric Digest, EDO-PS03-12. Letöltés: 2019.02.11. Web: https:// files.eric.ed.gov/fulltext/ED4 80540.pdf

Szarkáné Horváth, V. (1995). Az óvodai ének-zene foglalkozások módszertana. Nemzeti Tankönyvkiadó, Budapest.

Turmezeyné Heller, E. és Balogh, L. (2009). Zenei tehetséggondozás és képességfejlesztés. Kocka Kör Tehetséggondozó Kulturális Egyesület, Debrecen.

Vargha, B., Balogh, J., Nemeskürty, I. és Szabó, H. (1976). Müvészetre nevelés a családban. Kossuth Könyvkiadó, Budapest. 


\section{MELLÉKLETEK}

\section{1. számú melléklet: Szülői kérdőív}

1. Mi az Ön legmagasabb iskolai végzettsége?

( ) 8 általánosnál alacsonyabb

() 8 általános

() Szakiskola

() Szakmunkásképző

() Érettségi

( ) Felsőfokú szakképzettség

( ) Főiskolai diploma

( ) Egyetemi diploma

( ) Doktori cím

2. Ön mikor kezdte gyermeke zenei nevelését?

( ) Magzati korban (pl.: az anya énekelt a magzatnak, zenét hallgatott, stb.)

() Csecsemőkorban

() Mikor a gyermeke beszélni kezdett (kb. 1 éves kor)

() Óvodáskortól

() Nem kezdtem el

3. Milyen szerepet tölt be a zene családja életében?

() Fontos

( ) Elhanyagolható

4. Hallgat-e otthon a család zenét?

() Igen (Kérem, feleljen az 5-6. kérdésre is!)

( ) Nem (Kérem, ugorjon a 7. kérdésre!)

5. Milyen zenét hallgat? (Több választ is megjelölhet!)

() Komolyzene

() Népzene

() Könnyűzene

() Gyermekzene

( ) Cigányzene

( ) Egyéb: 


\section{Milyen hatással van gyermekére a zene? Kérem, tegyen X-et a táblázat megfelelö}

mezójébe! (Több válasz̆t is megjelölhet!)

\begin{tabular}{|l|l|l|l|l|l|}
\hline & $\begin{array}{c}\text { Érdeklödve } \\
\text { hallgatja }\end{array}$ & $\begin{array}{c}\text { Énekelni } \\
\text { kezd }\end{array}$ & $\begin{array}{c}\text { Táncol, } \\
\text { ritmusra } \\
\text { mozog }\end{array}$ & Megnyugtatja & $\begin{array}{l}\text { Nem mutat } \\
\text { érdeklődést }\end{array}$ \\
\hline Komolyzene & & & & & \\
\hline Népzene & & & & & \\
\hline Könnyűzene & & & & & \\
\hline Gyermekzene & & & & & \\
\hline
\end{tabular}

7. Játszik-e a családban valaki valamilyen hangszeren?

() Igen

( ) Nem

8. Milyen módon találkozike a gyermeke a zenével? (Több válasz̨ is megjelölhet!)

() Szülővel közösen énekel

( ) Más rokonnal (nagyszülővel, testvérrel, stb.) közösen énekel

() Rádiót hallgat

() Televízióban zenés műsort néz

( ) Lemezlejátszót hallgat

() CD lejátszót hallgat

( ) Szülő/rokon hangszerjátékát hallgatja

() Komolyzenei hangversenyt látogatnak

( ) Könnyűzenei koncertet, zenés műsorokat látogatnak

() Gyermekeknek szóló zenés műsorokat, koncerteket látogatnak

( ) Gyermekeknek szóló népi táncos programok

() Egyéb:

\section{Szokott-e énekelni gyermekének?}

() Igen (Kérem, feleljen a 10-11. kérdésre is, a 12-est pedig kihagyhatja!)

( ) Nem (Kérem, ugorjon a 12. kérdésre!) 
10. Milyen dalokat énekel gyermekének? (Több válasz̨t is megjelölhet!)

( ) Kis hangterjedelmú gyermekdalok (pl.: Hinta-palinta; Esik az eső; Katalinka szállj el)

() Népdalok

() Magyar könnyűzenei dalok

() Külföldi, idegen nyelvú dalok

() Egyéb:

11. Mikor énekel gyermekének? (Több választ is megjelölhet!)

( ) Közös játék közben

() Ha a gyermeknek rossz kedve van

() Elalvás előtt altatódalt

() Ha a gyermek unatkozik

() Utazás, sétálás, kirándulás közben

( ) Közösen végzett házimunka (pl.: rendrakás, mosogatás, főzés) közben

( ) Egyéb:

12. Miért nem énekel gyermekének, röviden fogalmazza meg! (Pl.: nem tartom fontosnak; rossz a hangom) Amennyiben énekel, erre a kérdésre nem kell válaszolnia!

13. Vannak-e otthon gyermekének zenélō jatékai, hangszerei? (Több válasæt is megjelölhet!)

( ) Boltban vásárolt játékhangszerek (pl.: xilofon, csörgődob, furulya, síp, triangulum, rumbatök, dob, csengettyük, tik fa stb.)

( ) Zenélő játékok (pl.: hangeffektekkel ellátott játékok)

( ) A gyermekkel közösen készített hangszerek (pl.: edényeken dobolás; csörgők készítése

babból; rázogató; csörgődob; gumiból pengetôs hangszerek; dió kasztanyetta stb.)

( ) Nincsenek otthon ilyen jellegü játékok

14. Többet énekel-e gyermeke otthon, mióta óvodába jár?

() Igen

() Nem 
15. Elújságolja-e gyermeke, ha ûj dalt, mondókát tanult azóvodában?

() Igen, szívesen el is énekli

() Igen, de nem énekli( ) Nem újságolja el

16. Tudja-e, hogy mely napok van az ének-zenei tevékenység az ön óvodájukban?

() Igen

() Nem

17. Kap-e tájékoztatást az óvónóktól, az éppen aktuális dal, mondóka anyagról (pl.: hirdetótáblára ki van rakva)?

() Igen

( ) Nem

18. Érdeklödik-e óvodapedagógusánál, hogy gyermeke... (Több válasz̨t is megjelölhet!)

() zenei képességei milyen mértékben fejlődnek?

( ) érdeklődik-e az ének-zenei foglalkozások iránt?

( ) végig részt vesz-e ezen tevékenységeken, vagy hamar megunja?

( ) kezdeményez-e énekes játékokat, vagy nem szívesen énekel, esetleg tart az énekléstől?

19. Kérem, válassza ki az alábbi felsorolásból, hogy Ön szerint mely képességek fejlódéséhez járul hozzá a zenei nevelés!

() Gondolkodás

() Emlékezet

() Ritmusérzék

() Éneklési készség

() Hallási készség

() Figyelem

() Önfegyelem

() Kreativitás

() Mozgáskoordináció

( ) Egyensúlyérzék

() Anyanyelvi képességek

() Matematikai képességek

() Társas kapcsolatok 


\section{Számú melléklet: Interjúkérdések}

1. Hány éve dolgozik óvodapedagógusként a pályán?

2. Milyen az óvodába érkező gyermekek etnikai összetétele, szociokulturális helyzete?

3. Mennyire érezhetők ezek az eltérések az intézményesített nevelésbe kerülő gyermekek zenei ízlésén, zenei preferenciáján?

4. Tapasztalhatók-e az IKT eszközök túlzott otthoni használatának negatív hatásai a gyermekek zenei ízlésében?

Érződik-e ízlésükön a modern könnyűzene preferenciája, túlsúlya, esetleg a napjainkban igen elterjedt televíziós tehetségkutató műsorok nyoma?

Gyakori-e, hogy a gyermekek olyan családokból érkeznek, melyre semmilyen zenei légkör nem jellemző?

5. Jelenleg milyen korösszetételű csoportja van?

6. Milyen szabályokat, módszertani alapelveket vesznek figyelembe az „Ének, zene, énekes játék, gyermektánc" tevékenységek megvalósítása során?

7. Készítenek-e az ének tevékenységek anyagát, célját, menetét tartalmazó éves havi vagy heti tervet?

8. Mennyire nehezíti meg a tervezést egy heterogén csoport esetén a gyermekek sokszor igen eltérô szociokulturális és zenei háttere?

Milyen eltérések figyelhetők meg a különböző szociokulturális háttérrel rendelkező, illetve a magyar és roma etnikumú gyermekek zene iránti érdeklődésében, zenei képességeik, készségeik fejlődésének idejében és tempójában?

Mutatkozik-e meg különbség a magasabb és alacsonyabb iskolai végzettséggel rendelkező szülők gyermekeinek zenei hátterében, zene iránti érdeklődésében, fejlődésében, ének tevékenységben való részvételében? 
9. Milyen szervezési módban valósul meg legtöbbször a gyermekek zenei élményszerzése (kötött, kötetlen, vagy spontán)?

A kötött forma hány éves kortól van jelen?

Mely formában lát legtöbb fejlesztő hatást a gyermekre nézve, és miért?

A tevékenységek az egész csoport részvételével, vagy mikrocsoportos formában valósulnak meg?

10. Hogyan oldható meg a sokszor igen eltérő egyéni képességekkel rendelkező gyermekek egyidejű fejlesztése az egyes ének tevékenységek során?

Van-e szükség egyéni képességfejlesztésre, ha igen, milyen rendszerességgel, és hány éves kortól?

11.Gyakran kezdeményeznek-e a gyermekek éneklést, szoktak-e játék közben maguktól énekelgetni?

Van-e már az óvodába kerüléskor igényük a közös éneklésre, vagy ez fokozatosan alakul ki náluk?

12. Örömmel vesznek-e részt a gyermekek a közös éneklésben, zenélésben?

13. Mennyire könnyű a gyermekek érdeklődését fölkelteni a zenei tevékenységek iránt, van-e erre valamilyen megszokott módszer, amely a gyermek motivációját segíti (pl.:

A gyermekek figyelme fenntartható-e a tevékenység végéig, vagy hamarabb megunják azt?

14. Milyen szempontokat vesznek figyelembe a gyermekeknek tanítandó dalanyag és a zenehallgatásra szánt anyag kiválasztásánál?

Honnan választják zenei forrásanyagukat?

Milyen arányban vannak jelen a magyar népdalok; a rokon, és más népek dalai; a magyar műzene és a klasszikus műzene darabjai a zenehallgatásra szánt dalanyagban? 
Figyelembe veszik-e a zenehallgatási anyag kiválasztásánál a multikulturalitást, a nemzetiségi, etnikai kisebbségek nevelése esetében, ha igen, hogyan?

15. Mely népszokásokat, hagyományokat ismertetik meg a gyermekekkel? Beépítik-e a tevékenységekbe az etnikai közösség hagyományait, zenei kultúráját?

16. Jelen van-e a tevékenységek során a néptánc, gyermektánc?

17. Milyen eszközök, hangszerek állnak az egyes korosztályok rendelkezésére, milyen gyakran, milyen céllal használják ezeket?

Használnak-e a gyermekek a csoportban általuk készített hangszereket?

18. A zenehallgatásra nevelés során milyen százalékban van jelen az éneklés, a hangszerjáték és a gépi zene?

19. Szokott-e megrendezésre kerülni az óvodában gyermekeknek szóló hangverseny, gyermekkoncert, esetleg valamilyen hangszeren jól játszó szülő csoportba történő meghívása?

20. Hogyan tájékoztatja az óvoda a szülőket az éppen aktuális dal- és mondókaanyagról (pl.: hirdetőtáblára ki van rakva)?

21. Érdeklődnek-e a szülők gyermekük zenei fejlődéséről, fejlesztéséről?

22. Vannak-e lehetőségek szülő és óvodapedagógus közti együttműködésre zenei nevelés területén, gondolok itt olyan közös programokra, ahol a szülők megismerhetik egy-egy délutáni zenei foglalkozáson pl.: Kodály elveit, az óvodában tanult dalokat, mozgásanyagokat, fejlesztési lehetôségeket; és van-e erre igényük a szülőknek?

Esetleg óvodai nyilt nap keretében a szülő megnézhet-e egy-egy „Ének, zene, énekes játék, gyermektánc tevékenységet”? 